\title{
Meta-analysis: Effect of problem approach and inquiry approach toward students' mathematical critical thinking skill over the past 4 years
}

\author{
Ida Dwijayanti ${ }^{*}$, Aryo Andri Nugroho', Yogi Indah Pratiwi ${ }^{1}$ \\ ${ }^{1}$ Universitas PGRI Semarang, Indonesia \\ $\square$ idadwijayanti@upgris.ac.id*
}

\author{
Article Information \\ Submitted May 10, 2019 \\ Revised April 11, 2020 \\ Accepted April 12, 2020 \\ Published June 16, 2020
}

Keywords

Critical Thinking;

Meta-Analysis;

Inquiry Approach;

Problem Approach.

\begin{abstract}
Several studies had been conducted to improve the critical-thinking ability through various models, including problem approach and inquiry approach. The purpose of this study is to analyze which model is the most influential to improve students' critical-thinking skills in the last 4 years of research. This type of research is a mixed-method (quantitative-qualitative which, involved 230 students in the classroom with the problem approach and 263 students with the inquiry approach. The data collection technique used was the documentation of research reports. The data analysis used was meta-analysis through effect size calculation and Z-test. The result shows that the problem approach has a greater influence on students' critical thinking skills than the inquiry approach. This is indicated by the average values of the effect size and Z-test respectively 0.9685 and 83.122 for the problem approach and 0.7207 and 77.162 for the inquiry approach.
\end{abstract}

\section{INTRODUCTION}

The industrial era 4.0 carries the concept of human-centered community technology and collaborates with technology to solve social problems (Shannon, 2008). For that, the development of capabilities that play a role in problem-solving becomes unavoidable. An important ability that must be possessed by students in the problems solving process is the critical-thinking ability (Johnson, 2009; Bermingham, 2015; Kivunja, 2015; Zare \& Othman, 2015). The Ministry of National Education emphasizes that one of the graduation standards for junior and senior high school students in the development of their critical thinking skills. the development of critical thinking skills becomes the focus of learning and becomes one of the graduation standards for middle and high school students. Critical thinking skills can be developed through learning strategies that prioritize problem-based learning, exploration, or discovery (Zakaria, 2015). Therefore, teachers can create learning strategies with nuances of exploration, discovery, or problem-solving. Such nuances in learning are known as learning approaches (Dwijayanti, 2018).

The problem approach is the nuance of learning that provides a learning environment with problems as the basis. It means learning begins with problems that must be solved (Yousefi \& Mohammadi, 2016; Fauziah et al, 2013; Herman 2007; Nurdyansyah 2018; Permana and Sumarmo 2007). Basically, in the problem approach, the students are asked to be more active in finding answers to problems given by the teacher. The problem is used as a context for students to learn critical thinking and problems solving skills, as well as to obtain essential knowledge and concepts from the subject matter (Brown \& Walter, 2014). By solving these 
problems, students can build their knowledge while developing critical thinking skills and problems solving skills. The inquiry approach is a nuance of learning that facilitates activities that focus on the search for knowledge or understanding to satisfy curiosity (Artigue \& Blomhøj, 2013). Furthermore, the inquiry approach is a series of learning activities that maximally involve all students' abilities to search and investigate systematically, critically, logically, and analytically so that they can formulate their findings with confidence (Goodchild et al, 2013).

Various studies have examined the effect of problem approaches on critical thinking skills, including Ariyanto et al, (2014) who concludes that the problems solving learning model can improve students' critical thinking skills through classroom action research. Octaria (2018) concludes that the inquiry approach with the process-oriented guided-inquiry learning (POGIL) model was effective in increasing students' critical thinking skills. Heo \& Chun (2018) and Suarsana, et al (2019) examine the effects of problem-posing and problem-solving on creativity using a problem approach based on the investigation. The results show a significant effect of the application of the model on the students' ability and creativity.

Research on the use of an inquiry approach to improving critical thinking skills has also been carried out. Hudha \& Batlolona (2017) examine the effectiveness of inquiry and discovery learning on students' critical thinking skills. Through the ANOVA test, it can be concluded that the two models are more effective in improving students' critical thinking skills compared to conventional learning. Robi et al, (2018) researched the analysis of the effect of discovery models on students' critical thinking skills. The critical thinking indicators used to refer to the critical thinking indicator P21 (having effective reasoning, using a thinking system, and making judgments and decisions). From the results of this study, it can be concluded that the application of discovery learning has a positive effect on developing students' critical thinking skills in solving two-dimensional arithmetic problems.

There are many studies out there that have proven the superiority of both approaches in improving students' critical thinking skills. The weaknesses of this study are the limited time of research and the absence of research sustainability. Also, this study uses a separate method to improve students' creative thinking abilities. The novelty of this research lies in the effectiveness of the problem approach and the discovery approach toward critical thinking skills over the past 4 years. One way that can be used to determine the magnitude of the influence each year is by conducting a meta-analysis method.

Meta-analysis is a method used to summarize and obtain the essence of the findings of several studies. In other words, meta-analysis is a technique summarizing from several similar studies to obtain quantitative data (Means et al, 2009; Cheung and Slavin, 2013). Conducting a meta-analysis of a research result is to draw a general conclusion from the results of research. The results obtained in each study are converted into the effect size (EZ). An effect size is a quantitative index that is used to summarize the study results in a meta-analysis. Effect size reflects the magnitude of the relationship between variables in each study. The relationship between meta-analysis and effect size is that meta-analysis is used to combine various research results and then combine them to find the combined effect size. The estimated value of the combined effect size is obtained based on the model used (Cheung and Slavin, 2013). Metaanalysis research has been used in learning mathematics. Peng et al, (2016) uses a meta-analysis method on 110 studies to find out the correlation between working memory and mathematical 
ability. Kul et al, (2018) uses a meta-analysis on 54 studies to determine the effectiveness of learning materials and mathematics classes. In Indonesia, Nugroho et al, (2020) uses metaanalysis to analyze the effect of discovery-based learning and environment-based learning on problem-solving abilities.

Research report documents as the focus of this research are studies that have been reported for the past 4 years. The problem approach is applied in a problem-based learning model while the inquiry approach is applied in the discovery of learning and inquiry learning models. Based on the background, it is necessary to analyze to find out the comparison of the effect of the problem approach and inquiry approach on students' critical thinking skills over the past 4 years.

\section{METHODS}

This study employed a mixed-method (quantitative-qualitative). The populations of this study were research reports in the form of a thesis or scientific journal within the last 4 years (20152018) which include the number of students, the average experimental and control class and the standard deviation of the control class. The samples used were theses or scientific journals with the problem approach and inquiry approach as the themes that affect the students' ability to think critically from several universities in Semarang. The sampling technique used was the purposive sampling technique.

The main instrument was the researcher because the researcher is responsible for planning, carrying out data collection, analyzing, and also reporting. Supporting instruments were observation guidelines and data collection aids. The procedures of the study were to determine the research domain, choose the type of publication, collect research results, record the data, calculate the effect sizes and test the average differences, and make reports. The data collection method used was the documentation technique while the data analysis method used was Meta-analysis. Besides, Z-test was performed as a comparison between meta-analysis and the ANOVA test to determine the comparative magnitude of the influence of the two approaches each year. To get a more complete description, especially data about the factors that affect students' critical thinking skills, a documentation study was conducted on the researchers' report on the implementation of the research and the results of the calculated effect sizes. The analysis of data about factors that influence the superiority of an approach in improving students' critical thinking skills is analyzed through descriptive methods.

Effect size calculation (Fritz et al, 2012) was done using the following formula:

$$
\Delta=\frac{\bar{X}_{E}-\bar{X}_{K}}{S_{K}}
$$

With $\Delta \quad$ : effect size

$\bar{X}_{E} \quad$ : the average of the experimental group

$\bar{X}_{K} \quad$ : the average of the control group

$S_{K} \quad$ : standard deviation of the control group

with the effect size criteria as follows.

$0<E S \leq 0,2 \quad$ : Small effect size

$0,2<E S \leq 0,8:$ Medium effect size

$0,8<E S \leq 2 \quad$ : High effect size 


\section{RESULTS AND DISCUSSION}

The results of the calculation of the effect size each year and the average effect size in the last 4 years for the problem approach and the inquiry approach can be seen in Table 1 .

Table 1. Average Effect Size Value of the Approaches' Effect on Students' Mathematical Critical Thinking Skill

\begin{tabular}{ccc}
\hline Year & Problem Approach & Inquiry Approach \\
\hline 2015 & 0,713 & 1,013 \\
2016 & 1,553 & 0,510 \\
2017 & 0,846 & 0,685 \\
2018 & 0,669 & 0,675 \\
\hline Average & 0,945 & 0,721 \\
\hline
\end{tabular}

Table 1 shows that the average effect size in the last 4 years for the problem approach is 0.945 and the inquiry approach is 0.720 . This shows that from 2015 to 2018, the use of problem approaches was better to improve students' creative thinking abilities compared to the inquiry approach.

Validity tests of the calculation results were carried out by conducting an ANOVA test to measure the difference in the average value of students' critical thinking skills annually and the Z-test to measure the average difference in the value of students' critical thinking skills over the past 4 years. However, before the ANOVA test was carried out. the researchers ensured that the data was normally distributed to further test its homogeneity. Based on the documentation study, it can be seen that each data was normally distributed so that the normality test was not carried out. The homogeneity test was carried out with the results as shown in Table 2.

Table 2. Homogeneity Test in Each Year

\begin{tabular}{|c|c|c|c|c|c|c|}
\hline Years & $\begin{array}{c}\text { Learning } \\
\text { Approaches }\end{array}$ & Variances & $\alpha$ & $F_{\text {observed }}$ & $F_{\text {critical }}$ & Conclusion \\
\hline 2015 & $\begin{array}{l}\text { Problem approach } \\
\text { Inquiry approach }\end{array}$ & $\begin{array}{l}101,7645 \\
94,769\end{array}$ & $5 \%$ & 1,0738 & 1,6477 & Homogeneous \\
\hline 2016 & $\begin{array}{l}\text { Problem approach } \\
\text { Inquiry approach }\end{array}$ & $\begin{array}{l}81,0016 \\
70,7667\end{array}$ & $5 \%$ & 1,144 & 1,6251 & Homogeneous \\
\hline 2017 & $\begin{array}{l}\text { Problem approach } \\
\text { Inquiry approach }\end{array}$ & $\begin{array}{l}146,7957 \\
111,0578\end{array}$ & $5 \%$ & 1,3217 & 1,6430 & Homogeneous \\
\hline 2018 & $\begin{array}{l}\text { Problem approach } \\
\text { Inquiry approach }\end{array}$ & $\begin{array}{l}106,6286 \\
181,2842 \\
\end{array}$ & $5 \%$ & 1,7001 & 1,7320 & Homogeneous \\
\hline
\end{tabular}

Table 2 shows that each year, the data of students' critical thinking skills come from populations with homogeneous variants so that further comparative tests can be carried out. The comparative test results of the average critical thinking skills of students in the class using a problem approach and the class using the inquiry.

Table 3. Comparative Test Results on Average Mathematical Critical Thinking Skills of Students in Each Year

\begin{tabular}{ccccccc}
\hline \multirow{2}{*}{ Year } & \multirow{2}{*}{$\alpha$} & \multicolumn{2}{c}{ DK } & \multirow{2}{*}{$F_{\text {observed }}$} & $F_{\text {critical }}$ & \multirow{2}{*}{ Conclusion } \\
\cline { 3 - 6 } & $5 \%$ & 3 & 122 & 5,358 & 2,678 & the average is different \\
2015 & $5 \%$ & 3 & 129 & 27,958 & 2,674 & the average is different \\
2017 & $5 \%$ & 3 & 123 & 2,737 & 2,678 & the average is different \\
2018 & $5 \%$ & 3 & 103 & 11,188 & 2,692 & the average is different \\
\hline
\end{tabular}


Table 3 shows that from 2015 to 2018, there were differences in the average critical thinking skills of students in the class using the problem approach and the class using the inquiry approach so that further testing is needed to find out which is more influential each year. By assuming the average critical thinking skills of students in the class using a problem approach is $\mu_{1}$ and the average critical thinking skills of students in the class using the inquiry approach is $\mu_{2}$, then the results of post-ANOVA test calculations were performed using the Schefee 'method successively as can be seen in Table 4, Table 5, Table 6 and Table 7.

Table 4. Post ANOVA Test in 2015

\begin{tabular}{ccc}
\hline Comparison & $F_{\text {observed }}$ & Conclusion \\
\hline$\mu_{1} v s \mu_{2}$ & 0,120 & $\mu_{1}=\mu_{2}$ \\
$\mu_{1} v s \mu_{3}$ & 11,921 & $\mu_{1}>\mu_{3}$ \\
$\mu_{1} v s \mu_{4}$ & 0,260 & $\mu_{1}=\mu_{4}$ \\
$\mu_{2} v s \mu_{3}$ & 10,196 & $\mu_{2}>\mu_{3}$ \\
$\mu_{2} v s \mu_{4}$ & 0,026 & $\mu_{2}=\mu_{4}$ \\
$\mu_{3} v s \mu_{4}$ & 9,925 & $\mu_{3}>\mu_{4}$ \\
\hline
\end{tabular}

Table 4 shows that the problem approach is better than the inquiry approach in increasing the effect on students' critical thinking skills in 2015.

Table 5. Post ANOVA Test in 2016

\begin{tabular}{ccc}
\hline Comparison & $F_{\text {observed }}$ & Conclusion \\
\hline$\mu_{1}$ vs $\mu_{2}$ & 0,086 & $\mu_{1}=\mu_{2}$ \\
$\mu_{1}$ vs $\mu_{3}$ & 18,858 & $\mu_{1}>\mu_{3}$ \\
$\mu_{1} v s \mu_{4}$ & 51,150 & $\mu_{1}>\mu_{4}$ \\
$\mu_{2} v s \mu_{3}$ & 27,436 & $\mu_{2}>\mu_{3}$ \\
$\mu_{2} v s \mu_{4}$ & 63,297 & $\mu_{2}>\mu_{4}$ \\
$\mu_{3} v s \mu_{4}$ & 10,422 & $\mu_{3}>\mu_{4}$ \\
\hline
\end{tabular}

Table 5 shows that the problem approach is better than the inquiry approach in increasing the effect on students' critical thinking skills in 2016.

Table 6. Post ANOVA Test in 2017

\begin{tabular}{ccc}
\hline Comparison & $F_{\text {observed }}$ & Conclusion \\
\hline$\mu_{1} v s \mu_{2}$ & 2,550 & $\mu_{1}=\mu_{2}$ \\
$\mu_{1} v s \mu_{3}$ & 0,577 & $\mu_{1}=\mu_{3}$ \\
$\mu_{1} v s \mu_{4}$ & 1,050 & $\mu_{1}=\mu_{4}$ \\
$\mu_{2} v s \mu_{3}$ & 5,760 & $\mu_{2}=\mu_{3}$ \\
$\mu_{2} v s \mu_{4}$ & 6,951 & $\mu_{2}=\mu_{4}$ \\
$\mu_{3} v s \mu_{4}$ & 0,082 & $\mu_{3}=\mu_{4}$ \\
\hline
\end{tabular}

Table 6 shows that the problem approach is better than the inquiry approach in increasing the effect on students' critical thinking skills in 2017.

Table 7. Post ANOVA Test 2018

\begin{tabular}{ccc}
\hline Comparison & $F_{\text {observed }}$ & Conclusion \\
\hline$\mu_{1}$ vs $\mu_{2}$ & 3,42 & $\mu_{1}=\mu_{2}$ \\
$\mu_{1} v s \mu_{3}$ & 1,113 & $\mu_{1}=\mu_{3}$ \\
$\mu_{1} v s \mu_{4}$ & 19,97 & $\mu_{1}>\mu_{4}$ \\
$\mu_{2} v s \mu_{3}$ & 7,641 & $\mu_{2}=\mu_{3}$ \\
$\mu_{2} v s \mu_{4}$ & 5,042 & $\mu_{2}=\mu_{4}$ \\
$\mu_{3} v s \mu_{4}$ & 29,336 & $\mu_{3}>\mu_{4}$ \\
\hline
\end{tabular}


Table 7 shows that the problem approach is better than the inquiry approach in increasing the effect on students' critical thinking skills in 2018.

The analysis of students' average critical thinking skills in the last 4 years was conducted to find out whether the average learning outcomes using the problem approach was better than the inquiry approach toward critical thinking skills. The Z-test results can be seen in Table 8 .

Table 8. the Average Different Test Of Students' Mathematical Critical Thinking Skills Over the Past 4 Years

\begin{tabular}{|c|c|c|c|c|c|c|}
\hline $\begin{array}{l}\text { Learning } \\
\text { Approaches }\end{array}$ & $n$ & Average & Variances & $Z_{\text {observed }}$ & $Z_{\text {critical }}$ & Conclusion \\
\hline Problem approach & 230 & 83,122 & 116,716 & \multirow{2}{*}{6,138} & \multirow{2}{*}{1,64} & \multirow{2}{*}{$\begin{array}{c}\text { The average is } \\
\text { different }\end{array}$} \\
\hline Inquiry approach & 263 & 77,162 & 114,421 & & & \\
\hline
\end{tabular}

Table 9 shows that over the past 4 years, the problem approach has had more influence on students' critical thinking skills when compared to the inquiry approach.

One of the factors that encourage students' critical thinking skills is the presentation of material that is related to real-world problems through the help of interesting media. However, some problems emerge because of the not-routine investigations done by the students. Material related to the real world allows students to visualize it easily. The ability to manipulate this visualization is needed in the critical thinking process as one of the higher cognitive abilities (Salazar, 2012; Kazak, 2015; Dwijayanti, 2019). Another supporting factor is motivation while the factors that inhibit students' critical thinking skills are their lack of curiosity. This causes the problem approach to have more opportunities to influence the improvement of students' thinking abilities. The problem-based approach is a learning environment with problems as the basis (Yousefi \& Mohammadi, 2016). The problem is used as a context for students to learn critical thinking and problem-solving skills, as well as to obtain essential knowledge and concepts from the subject matter (Brown \& Walter, 2014). While the inquiry approach is learning that facilitates activities that focus on the search for knowledge or understanding to satisfy curiosity (Artigue \& Blomhøj, 2013; Goodchild et al, 2013). If the students' curiosity is less developed, it is difficult for them to search and investigate systematically, critically, logically, and analytically, as well as to formulate their findings. This is by research conducted by Dwijayanti which states that the provision of problems can affect the improvement of HOTS abilities including the ability to think critically and creatively (Ariyanato et al, 2018; Dwijayanti, 2016; Octaria, 2018; Heo \& Chun, 2018; Suarsana, 2019).

Overall, the factors that encourage students' critical thinking skills are the presentation of material that is related to the real world through attractive media assistance although some problems emerge related to the non-routine investigation. On the other hand, the factors that hinder students 'critical thinking skills are unprepared strategies, inefficient time management, and unequal students' curiosity.

\section{CONCLUSIONS}

Based on the results of the study, it can be concluded that the problem approach has a greater influence on students' critical thinking skills than the inquiry approach. This is indicated by the average value of the effect size of the problem approach which is 0.9685 (the criterion of 
influence is high) and the inquiry approach which is 0.72075 (the criterion of influence is moderate). This calculation is supported by the results of calculations through the $Z_{\text {test }}$ which produces $\mathrm{Z}_{\text {observed }}=6.138>1.64=\mathrm{Z}_{\text {critical, }}$, with an average value of 83.122 for critical thinking skills in the problem approach and 77,162 in the inquiry approach. Other findings that can be obtained in this study are the factors that encourage and hinder the students' critical thinking skills, the factors that encourage students' critical thinking skills are the presentation of material that is related to the real world through attractive media assistance although some problems emerge related to the non-routine investigation. On the other hand, the factors that hinder students 'critical thinking skills are unprepared strategies, inefficient time management, and unequal students' curiosity.

It is suggested for the teachers to use the problem approach rather than the inquiry approach. As for the implementation of learning with the problem-based approach in learning, teachers should arrange a time as effectively as possible from the beginning to the end, reinforce students, and build good communication with students to develop students' curiosity.

\section{AUTHOR CONTRIBUTIONS STATEMENT}

ID worked as the principal investigator for this research project. The study was designed, conceptualized and carried out by him. She had major contribution in devising theoretical framework and reviewing literature pertaining to the study. AAN and YIP had been an integral part of the whole process from brainstorming to writing her input has always been important. She played an important role in data collection and analysis.

\section{REFERENCES}

Ariyanto, M., Kristin, F., \& Anugraheni, I. (2018). Penerapan model pembelajaran problem solving untuk meningkatkan kemampuan berpikir kritis dan hasil belajar siswa. Jgk (Jurnal Guru Kita), 2(3), 106-115.

Artigue, M., \& Blomhøj, M. (2013). Conceptualizing inquiry-based education in mathematics. ZDM, 45(6), 797-810.

Bermingham, M. (2015). Clearing up "critical thinking": Its four formidable features. Creative Education, 6(04), 421-427.

Brown, S. I., \& Walter, M. I. (2014). Problem posing: reflections and applications. Psychology Press.

Cheung, A. C., \& Slavin, R. E. (2013). The effectiveness of educational technology applications for enhancing mathematics achievement in K-12 classrooms: A meta-analysis. Educational research review, 9(1), 88-113.

Dwijayanti, I., Budayasa, I. K., \& Siswono, T. Y. E. (2019). Students' gestures in understanding algebraic concepts. Beta: Jurnal Tadris Matematika, 12(2), 133-143.

Dwijayanti, I. (2018). Paradigma pendidikan, teori belajar serta aplikasi dalam strategi pembelajaran matematika. Semarang: Universitas PGRI Press.

Dwijayanti, I. (2016). Pengembangan perangkat pembelajaran matematika berbasis pendidikan multikultural menggunakan socio humanism. JIPMat, 1(1), 10-18. 
Fauziah, R., Abdullah, A. G., \& Hakim, D. L. (2013). Pembelajaran saintifik elektronika dasar berorientasi pembelajaran berbasis masalah. Invotec 9(2), 165-178.

Fritz, C. O., Morris, P. E., \& Richler, J. J. (2012). Effect size estimates: Current use, calculations, and interpretation. Journal of experimental psychology: General, 141(1), $2-18$.

Goodchild, S., Fuglestad, A. B., \& Jaworski, B. (2013). Critical alignment in inquiry-based practice in developing mathematics teaching. Educational Studies in Mathematics, 84(3), 393-412.

Heo, H. J., \& CHun, B. A. (2018). Improving the higher order thinking skills using flipped learning: Focused on the in-class activities with problem posing and solving. ASIA LIFE SCIENCES Supplement, 15(4), 2187-2199.

Herman, T. (2007). Pembelajaran berbasis masalah untuk meningkatkan kemampuan berpikir matematis tingkat tinggi siswa sekolah menengah pertama. Educationist 1(1):47-56.

Hudha, M. N., \& Batlolona, J. R. (2017). How are the physics critical thinking skills of the students taught by using inquiry-discovery through empirical and theorethical overview?. Eurasia Journal of Mathematics, Science and Technology Education, 14(2), 691-697.

Johnson, E. B. (2009). Contextual Teaching \& Learning. Bandung: Mizan Learning Center.

Kazak, S., Wegerif, R., \& Fujita, T. (2015). The importance of dialogic processes to conceptual development in mathematics. Educational Studies in Mathematics, 90 (2), 105-120.

Kivunja, C. (2015). Using de bono's six thinking hats model to teach critical thinking and problem solving skills essential for success in the 21st century economy. Creative Education, 6(03), 380-391.

Kul, Ü., Çelik, S., \& Aksu, Z. (2018). The impact of educational material use on mathematics achievement: a meta-analysis. International Journal of Instruction, 11(4), 303-324.

Means, B., Toyama, Y., Murphy, R., Bakia, M., \& Jones, K. (2009). Evaluation of evidencebased practices in online learning: A meta-analysis and review of online learning studies. Washington DC: U.S Department Education.

Nugroho, A. A., Dwijayanti, I., \& Atmoko, P. Y. (2020). Pengaruh model pembelajaran berbasis penemuan dan lingkungan terhadap kemampuan pemecahan masalah matematika melalui meta analisis. AKSIOMA: Jurnal Program Studi Pendidikan Matematika, 9(1), 147-157.

Nurdyansyah, N. (2018). Model pembelajaran berbasis masalah pada pelajaran IPA materi komponen ekosistem. Universitas Muhammadiyah Sidoarjo.

Octaria, E. A. (2018). Pengaruh model process oriented guided inquiry learning (POGIL) terhadap kemampuan berpikir kritis matematis. (Bachelor's thesis, Jakarta: FITK UIN Syarif Hidayatullah Jakarta).

Peng, P., Namkung, J., Barnes, M., \& Sun, C. (2016). A meta-analysis of mathematics and working memory: moderating effects of working memory domain, type of mathematics skill, and sample characteristics. Journal of Educational Psychology, 108(4), 1-19. 
Permana, Y., \& Sumarmo, U. (2007). Mengembangkan kemampuan penalaran dan koneksi matematik siswa SMA melalui pembelajaran berbasis masalah. Educationist, 1(2):116123.

Robi, A. A., Hobri, H., \& Dafik, D. (2018). The analysis of critical thinking skill of version p21 in solving the problems of two dimensional arithmetic derived from the implementation of guided discovery learning. International Journal of Scientific Research and Management, 6(01), 6-13.

Salazar, R. F., Dotson, N. M., Bressler, S. L., \& Gray, C. M. (2012). Content-specific frontoparietal synchronization during visual working memory. Science, 338(6110), 10971100 .

Shannon, S. V. (2008). Using metacognitive strategies and learning styles to create self-directed learners. Institute for Learning Styles Journal, 1(1): 14-28.

Suarsana, I., Lestari, I. A. P. D., \& Mertasari, N. M. S. (2019). The effect of online problem posing on students' problem-solving ability in mathematics. International Journal of Instruction, 12(1), 809-820.

Yousefi, S., \& Mohammadi, M. (2016). Critical thinking and reading comprehension among postgraduate students: The case of gender and language proficiency level. Journal of Language Teaching and Research, 7(4), 802-807.

Zakaria, G. A. N., Mahalle, S., Bakar, Z. A., \& Nawi, A. (2015). Collaborative learning in the teaching of usul fiqh (islamic jurisprudence) at the pre-university level in Brunei Darussalam. Mediterranean Journal of Social Sciences, $6(3$ S1), 158-182.

Zare, P., \& Othman, M. (2015). Students' perceptions toward using classroom debate to develop critical thinking and oral communication ability. Asian Social Science, 11(9), 158-170. 
Dwijayanti, I., Nugroho,, A. A., \& Pratiwi, Y. I. 